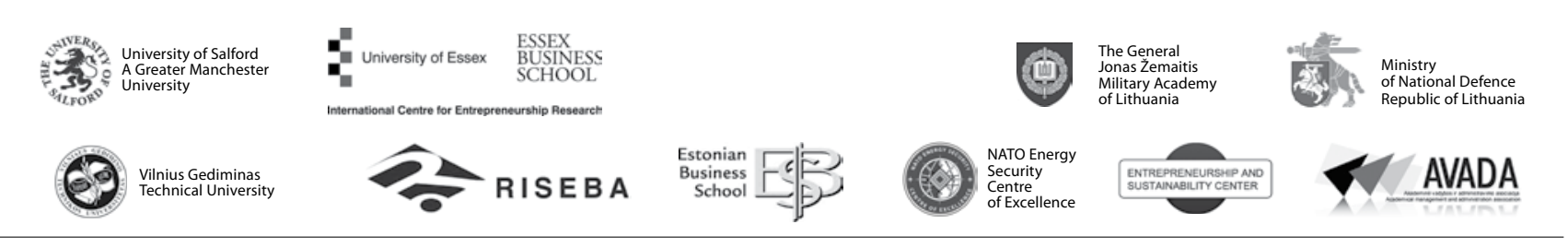

\author{
JOURNAL OF SECURITY AND SUSTAINABILITY ISSUES \\ ISSN 2029-7017 print/ISSN 2029-7025 online \\ 2017 June Volume 6 Number 4 \\ http://doi.org/10.9770/jssi.2017.6.4(15)
}

\title{
ECONOMIC SECURITY AND INTERNATIONAL RELATIONS IN THE EUROPEAN UNION
}

\author{
Rimma Azamatova1, Zalina Shadova ${ }^{2}$, Bela Shorova ${ }^{3}$ \\ ${ }^{1,2,3}$ Kabardino-Balkarian State University named after H.M Berbekov, \\ Chernyshevsky str. 173, 360 004, Nalchik, Russian Federation \\ E-mails:'armwork7@mail.ru, 22zschadova@rambler.ru, ${ }^{3}$ bela.shorova@mail.ru
}

Received 16March 2017; accepted 26 April 2017

\begin{abstract}
Our paper is dealing with the issues of economic security and international relations in the European Union (EU) at the uncertain times of rethinking European security and sustainability in the face of Brexit and other challenges facing Europe.

The paper focuses on the EU issues from the point of view of the outside observer. It also discusses the EU neighborhood policies, EU energy balance and power nexus, as well as other economic and political challenges that might undermine the position of the EU in the rapidly changing world.

We analyze the EU economic and energy strategy and discuss the implications of Brexit on the EU economy and security in the world affairs. The paper tackles such important issues as energy security, economic security, international trade in the EU and the future of the Eurozone. Our results and implications might be useful for relevant policy-makers, EU decision-makers, relevant stakeholders as well as for the citizens of the EU residing both in the "new" and the "old" Member States who might want to get a non-involved expert insight into the European affairs and that possible pathways of its future development.
\end{abstract}

Keywords: economic security, national security, international trade, energy, international relations

Reference to this paper should be made as follows: Azamatova, R; Shadova, Z.; Shorova, B. 2017. Economic security and international relations in the European Union, Journal of Security and Sustainability Issues 6(4): 711-718. http://doi.org/10.9770/jssi.2017.6.4(15)

JEL classifications: F01, F52, P45

\section{Introduction}

Nowadays, the EU stands at the crossroads of international politics and economic development searching for the new pathways to follow and the new wind to be found for its sails. Many recent events shattered its position and its perspectives for further deepening and enlargement. National security issues are becoming a number one priority in the EU. Wide array of national security facets is being discussed, but energy security issues remain among the most urgent ones (Baublys et al., 2015; Jefremov, Rubanovskis, 2015; Tvaronavičienè et al., 2015; Navickas et al., 2017; Genys, 2016; Tvaronavičienè, 2016; Schröder, Prause, 2015; Strielkowski et al., 2016a; de Espona , 2016; Oates et al., 2017).

Generally, in European Union, the discussion of national security has mainly been shaped by the gas crises of 2006 and 2009, the time when Russian gases stopped to flow via Ukrainian pipelines caused by disputes between the two nations over the prices of gas as well as debts. The crises took place amidst mounting fears of resource nationalism in exporters of energy, and in the context of high prices of oil. The main concern was 
the economies of Europe were susceptible to political pressure from the exporters of energy and to strategic rivalry with resource-hungry China. However, today, fears of supply seem less salient. Energy security has been defined in various ways and such definitions range from narrow issues of disruption of physical supply to wider ones which involve the political, environmental and economic consequences of shifts in energy markets (Dreyer and Stang, 2013; Balitskiy et al., 2014).

Nevertheless, the simplest definition which the International Energy Agency uses to refer to energy security is "the uninterrupted availability of energy sources at an affordable price." Attainment of this security needs efforts for reducing risks to the systems of energy, both external and internal, and to create resilience so as to manage the remaining risks. Tools for achieving this include making sure that markets operate so that demand forces and supply match, development of enough production as well as transport infrastructure, expansion systems of risk management (alternative supply routes, emergency planning and reserves), maintenance of a diversified energy suppliers' portfolio, and controlling demand (energy efficiency) (Comolli, 2010). However, considerations of energy security ought to be balanced against environmental and competitiveness forces; particularly those which relate to climate change.

The economic crisis in Europe, its economy's maturity, its stagnant demographics and its attempts to decrease fossil fuel use are reducing expectations of future demand of energy. Perhaps, imported gas is possible to comprise 80 percent of consumption by the year 2030 as a result of falling domestic production in the Netherlands and the United Kingdom. Even though the European Union is thought to has a substantial quantity of shale gas which might contribute to its security of supply, forecasts for development seem bleak in most member states because of strong environmental hostility and uncertainty concerning the real extent of deposits. In spite of ambitious targets, the European Union energy mix shifted somehow between 1995 and 2011. The nuclear energy's contribution remained constant at 14 percent of gross inland consumption, whereas the usage of renewables (from 5 to 10 percent) and gas (from 20 to 24 percent) came at the expense of petroleum products (from 39 to 35 percent) to coal (from 22 to 17 percent) (Bilan et al., 2017; Dreyer and Stang, 2013).

All energy sources have their own risk profiles, with some more vulnerable to interruptions of external supply. Generally, nuclear plants keep adequate fuel on site to run for over two years. There is plenty of coal, and it is fungible and cheap. Development of renewable energy has been a widely domestic process up to the present date. Consequently, for these fuels at least, disruptions of external supply are not viewed to pose a significant risk. Ever since the 1970s first oil shocks, European nations have taken steps including diversification of suppliers, the creation of substantial facilities for storage of oil, and reduction of the significance of oil in their economies, as a way of ensuring that considerable shortages of does not pose a threat like before. But, it is the interruptions of supply of natural gas that has have resulted in the most worries because of the transport mechanisms involved (long pipelines from Algeria, Norway or Russia) and detrimental contractual measures.

The European Union has sought after enhancing energy security through the construction of a resilient, open and interconnected internal market, while it pursues a rules-based, multifaceted approach globally. The Energy Charter Treaty (ECT) of 1994 gave an outline of rules for transporting energy, investment protection, settlement of disputes and cooperation on environmental problems. Though high hopes were bestowed on the ECT, despite signing, Russia never approved it. On the other hand, Moscow withdrew from it in 2009 and in the same year cut off gas to Europe in the course of its conflict with Ukraine (Comolli, 2010). The European Union policy response to the crises of gas of the past decade has been a reinforced determination to make markets of gases more open through questioning monopolistic clauses in long-term contracts of supply signed with outside suppliers of energy, establishing antitrust cases against energy utilities (which comprise many EU firms and a ground-breaking case against Gazprom), formulating standards and responsibilities for supply security and promotion of better interconnectivity amongst isolated domestic markets in the new Eastern and Central European member countries through pipeline reserve flows and interconnector pipelines. 


\section{Energy security and environmental sustainability in the EU}

Currently, the issue if gas and oil security are no more a major concern. Rather, it is the continued plenty of fossil fuels, particularly coal, which is the primary worry. The ready availability of coal makes it hard to reduce the consumption of fossil fuels and carbon dioxide emissions. The Climate policy of the Union is very ambitious; though it encounters some challenges. Main measures have been the launching of an ETS (carbon emission scheme) and obligatory targets for renewable energy (a decrease of 20 percent compared to 1990) as of 2020). Nevertheless, low prices of carbon, as well as the rejection of nuclear power in Germany, have resulted in new dependence on coal. Thus, even with lower energy consumption throughout the economic crisis, the European Union is not able to meet its own carbon dioxide emission goals. Given that the EU's own domestic strategy of climate is revealing its constraints could as well reduce the influence of EU in the international climate policy platform, remarkably for talks on a successor to the Kyoto Protocol of 1997(Dreyer and Stang, 2013; Strielkowski and Lisin, 2013).

With regard to the above, the raising importance of renewable energy sources in the EU becomes apparent. Figure 1 that follows shows the EU energy balance in 1990-2015.

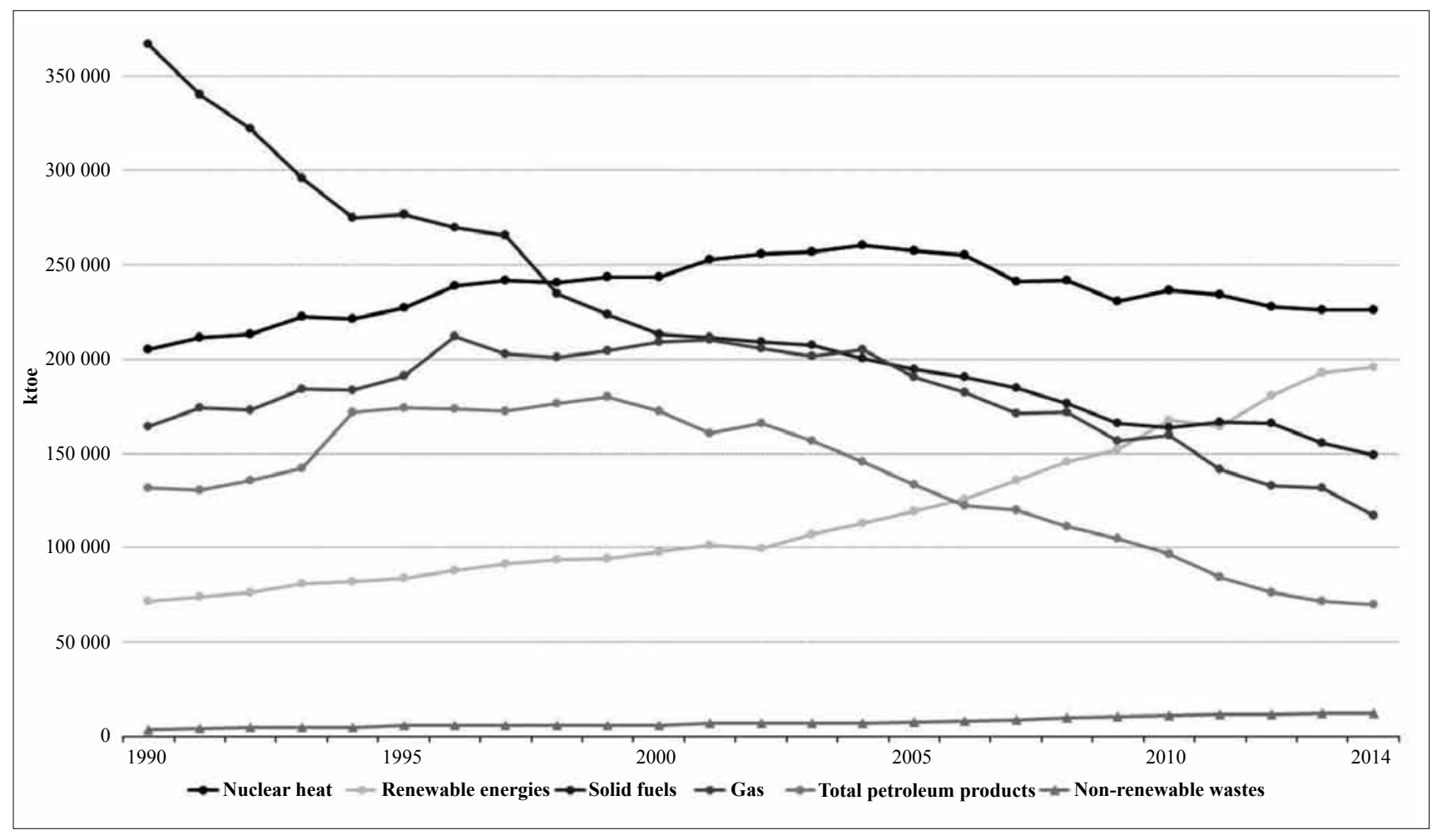

Fig. 1. EU energy balance (1990-2015)

Source: Eurostat (2016)

The implementation of the existing climate policies leads to the emergence of fresh energy security concerns. The greatest security challenge in the present day is how to control the essential economy decarbonization while preventing the interruption of electricity markets. Intermittent renewable energy sources; solar and wind power have been expanding fast, for instance, and transmission grids have undergone through difficulties adapting to the resultant irregular power influxes (see Figure 1). Conventional plants of generation; nuclear, coal and gas are being forced into backup functions with plants being left idle new investments postponed, and utility companies placed under pressure by rambling indicators of pricing. Under such circumstances, it is impossible to rule out main electricity blackouts. 


\section{Difference between the old EU and new EU Member States}

Apart from employment protection laws that have been converging, various institutions of the labor market in old and new EU Member States like labor union destiny and wage bargaining coordination still vary considerably. Such institutions of the labor market as well differ amongst the new EU members, with the Baltic nations being much more liberal compared to the others. Overall, there are various differences between the old and new EU member states. Fundamentally, labor markets are in general viewed as being more flexible in the new EU members than the old ones. Labor market institutions in the new EU members are different from the older members for two key reasons(Rovelli, 2016).

To begin with, the institutional mechanisms established in the socialist period for the protection of labor did not endure the transitioning to capitalism many transition economies, therefore, entered the 1990s with less labor protection vestiges. Also, since the economic systems of the new EU members were quite under-developed, these states would not afford to establish costly institutions of labor market like unemployment benefits as well as active labor policies of the market. Thus, these institutions are frequently undersized in the new EU members. Similar conditions did not have an impact on certain other labor market institutions like employing and firing limitations and other protection regulatory instruments of employment which affect labor unions and wage bargaining (Rovelli, 2016).

Moreover, the distinction between the "old" and the "new" EU Member States might be searched in the approach to economic realm and the rule of law that were shaped by the economic transformation of the 1990s that went hand in hand with such unpleasant by-products as for example corruption and tax evasion (see e.g. Koudelková et al., 2015; Čábelková and Strielkowski, 2013; or Strielkowski and Čábelková, 2015).

\section{Impacts of Brexit on the EU security and disintegration of the $E U$ in the future}

Some scholars have attempted to analyze the effect of Brexit on the future of EU. The negative economic impacts of greater trade barriers are among the reasons to be worried about Brexit. However, not everybody is concerned about the impact Brexit has on the EU's future. Definitely, there is the argument that the United Kingdom was an enemy of higher European integration and that the European Union without the obstructions of the UK might pursue more cohesive policies which focus on greater integration. Particularly, the assertion is that the absence of the United Kingdom could make it easier to focus on policies which will assist in making a success of the euro as a shared currency, for example, a shared deposit insurance scheme or a common insurance program of unemployment. Conversely, there is another view which suggests that the United Kingdom has traditionally been a strong supporter of economic reforms which enhance growth like the completion of the single market as the maintenance of free trade across the globe. Therefore, without the voice of UK at the EU's debating table, the possibility of reforms which enhance growth in future years is reduced (Karl, 2016; Oliver and Williams, 2016).

The day of the $29^{\text {th }}$ of March 2017 marked yet another historic moment; one that had a significant effect not only on the European economy but also on the entire world's economy. This is the day that Britain submitted its notice of quitting the European Union. This move is likely to have a major effect on business across Europe, owing to the fact that a member who chooses to leave is stripped off the benefits they were initially accustomed to. In order to further elucidate on the subject matter at hand, this analysis will look at the economic implications of Brexit on the European Union, Euro currency, and the EU Single Market.

\section{Implications for the security and international relations in the European Union}

Britain`s exit from the European Union will definitely create a big challenge for other member states. One of the greatest challenges that they will have to face now that the second largest EU contributor is no longer part of the team is, filling in the shortfall out of their contributions. Britain was one of the top contributors of the European Union. In 2016, for instance, its annual budget was agreed at $£ 16$ billion (Kauders, 2016). This was inclusive of custom duties it had to pay for being part of the EU. In return, it used to receive up to 7 billion euros worth of sub- 
sidy. With its premature exit, Britain now leaves a loophole of 5 percent which other members are obliged to fulfill. According to IFO situated in Germany, their country which is arguably the chief contributor has no option but to offer an additional 2.5 billion euros in order to fill in the void left behind by Britain (Burrage, 2016). This will actually be a major challenge owing to the fact that the country is already offering a lot to the Union. According to UniCredit, a possible eventuality would be the consistent management of more negatives within the euro confines. It is, however anticipated that the Union will seek to take a financial flight to secure itself while uncertainty looms leading to the culmination of an even tighter budget for them. The current Gross Domestic Product would definitely have to be revised.

It is estimated that the current trade surplus of the European community stands at 100 billion euro (Shipman, 2017). Britain alone is known to seek external goods and services amounting to 20 billion(Shipman 2017). It is therefore apparent that the Brexit will result to the weakening of the EU since a lot of resources formerly exported to Britain will have to be rescinded. This would be disadvantageous owing to the fact that they contribute 2.6 of the total GDP of the Union.

The reintroduction of the tariffs to be imposed on the deserter will end up leading to a "demand shock" (Oliver, 2016). In turn, this would result in a significant drop of the GDP by up to $0.26 \%$ (Oliver, 2016). Britain's exit is therefore very critical to the European Union to an extent that the they may have to comply to the terms and conditions of the superpower. This means submitting to their requirements for continued freedom in terms of all provisions except having to accept outsiders into their countries to enjoy significant benefits being enjoyed by the rest of the nationals.

It was implied that the momentous exist resulted from Britain`s dissatisfaction with immigrants moving into their country and enjoying privileges that most of them end up not earning. This would greatly affect the European market owing to the fact that more than 1.2 million workers were reported to be in Britain in 2015 (Cini andPérez-Solórzano, 2015). The effect would mostly affect countries with large numbers of immigrants in Britain such as Poland. Nations with significant affluence equal to that of Britain would, nonetheless, be forced to accept more immigrants. This would greatly impact on their economic viability.

Bertelsmann, a research foundation based in Europe intimates that Britain's exit is bound to affect other countries such as Ireland more than it would affect the former. This is due to their great dependence on the nation. The impact that this withdrawal would have on Britain is termed as a "soft exit" (Macshane, 2015).

Other countries that are likely to be devastated by the sudden change of events are Benelux counties. The impact would, however, be minimal on Germany since the country has other external markets for their manufactured commodities. Belgian Region of Flanders is also anticipated to experience a significant drop on its GDP pending the exit. Other dynamic effects likely to be experienced involve reduction in the general productivity of the European Union due to reduced internal competition.

Brexit also has the potential to reduce the integration between Britain and the EU. In addition to this, heightened uncertainty is bound to arise following the introduction of negotiations meant to institutionalize the trading domain. Some of the great leaders in the EU appear to be opposed to the negotiations that Britain seeks to bring to the table. The German chancellor Angela Merkel, for instance, intimated that it is impossible for a nation to avoid the challenges while only gaining consistent benefits.

This implied that she was unhappy with the fact that Britain wanted to continue enjoying all of the freedoms of the Single Market being entitled to the rest of the European Union nations, expect the freedom of free movement. According to her the suggestion is preposterous and the debates of how to "punish" Britain for exiting the EU are on-going. While in the first stage of these debates the EU established itself into the position of a mentor threatening to charge Britain "billions of Euros" for leaving the EU, the balance is slowly shifting towards Britain which is now claiming it will be the EU who would have to compensate their country for leaving. 


\section{Security implications for the Eurozone}

Brexit is bound to result to some detrimental consequences regarding Europe's most used currency. It is highly anticipated that following the exit, the currency is bound to lose value. This is likely to favor Britain traders since a loss of value in the currency is likely to result in cheaper exports (Macshane, 2015). This would in turn increase their overall productivity, thus implying that the Brexit is going to favor traders. The European Union block is likely to be affected by this change owing to the fact that their resources will lose their value with time making it difficult for them to recover the amount they are seeking to fill in the void left behind by Britain.

A decline in the value of the Euro will adversely affect many sectors of the economy. There is bound to be an influx in commodities, leading to a reduction in demand and hence a lot of resources may end up going to waste. A key thing to note is that only those British companies that are well connected to the other markets despite the European Union will stand to benefit. Others may end up collapsing following closed ties between British and the EU since they will no longer have a market for their produce. Those who had anticipated the Brexit may be at a vantage point compared to those who chose to ignore earlier signs.

Investors on the other hand, are also likely to transfer their resources to other markets such as the dollars which they presume are safe havens owing to the recent change of the events. This is likely to result in a reduction in overall investment within Europe and in the end it may have detrimental consequences on the banking sector which highly relies on these investors. As such, the financiers will now be more risk averse than ever before (Oliver, 2016). The Brexit is, therefore, not only anticipated to affect one currency, instead it may end up leading to negative repercussions on others as well owing to the great insignificance and inconsistency of trade being experienced.

\section{Security implications for the EU Single Market}

European Union is considered to be one of the largest markets in the world. This means that the exit of one of the most strategic partners is undoubtedly going to affect the entire market. Countries that formerly exported commodities into Britain may have to opt for other markets for their goods. In turn, Britain is bound to lose since their exit will reintroduce tariffs that will end up increasing the cost of commodities moving from Britain to other European countries. The commercial viability of labor is bound to be a thing of the past since Britain has opted not to accept external immigrants. A matter that is bound to affect some of their sectors requiring manual laborers (Strielkowski et al., 2016b). It is anticipated that in the near future, Britain will be clamoring for external labor owing to the impending demand for labor.

Brexit is also anticipated to negatively affect the global role of the European Union. Some tend to think that this may be the beginning of other countries` eventual exit, since they may end up not gaining substantial benefit as before, and hence these exits may result in the collapse of the EU (Shipman, 2017). Further still, the Brexit is likely to result in the breakdown of freedoms that the United Kingdom was initially accustomed to. This may end up demolishing the free trading block owing to the fact that restrictions will have to be imposed on goods moving in and out of the Britain. Approximately 44\% of Britain`s exports go to the European Union, therefore, unless negotiations bear fruits the country may have to seek other eternal markets and that is no small task at all (Shipman, 2017).

It is possible for Britain to gain access to the EU Single Market despite its exit. The nation could come to terms with the European Union to in order for them to continually undertake free trading activities despite being a non-member. This would avoid any unnecessary strains that may come about due to reintroduction of strict levies imposed on other non-members. Scarpering a trade pact that would involve an amicable solution as the one formerly proposed would have a major impact on the EU. There is thus no other option left for the Union other than to comply with the proposal.

It is evident from the above illustrations that the Brexit is one of the greatest shocks in recent times. This even 
has led to a lot of uncertainty regarding what the future holds for the European Union. It resulted from the idea that the Great Britain was finally weary of the large influx of immigrants who move into the country and enjoy benefits equal to those of other nationals without earning such privileges. It is thus saddening that Britain had to leave uneventfully, however, some negotiations have to be made in order to ensure that that neither the European Union nor Britain gets to suffer due to the changes made. All that is left now is for us to wait and see what happens in the near future before one can decide whether this decision was wise or imprudent.

\section{Conclusions and discussions}

Overall, it seems that the economic security and international relations in the European Union have been influenced by a plethora of important changes. Brexit, energy issues and the role of the EU in the international relations as a major global player threaten to undermine its otherwise strong and solid position as one of the world's leading economies.

The EU is now facing harsh times with threats not only to its economic and political security but to its sheer existence coming from all sides. With regard to the competition from other leading economies, such as China, India, Brazil or the United States, the EU needs to collect itself and to find new ways for consolidating its economic and international position as well as how to solidify its internal affairs.

Energy security might be one important thing to follow. With the dependence on Russian gas and oil, the EU has to reinvent its climate and energy policy and to invest more into the renewable energy sources. Moreover, it needs to introduce comprehensive policies in order to enable all of the above.

When it comes to Brexit, this might not be the last initiative of the EU country to leave the union - there might be more countries willing to follow. What needs to be done is to find the new unifying idea to bind all Member States for one common goal that might either be the creation of a federation or confederation. All in all, the EU needs to find a new place in the troubled world of tomorrow that would be full of threats ranging from economic instability to terrorism. One can only reckon that the European Union has very decent chances to survive in this new world.

\section{Acknowledgements}

This paper has been supported by the ERASMUS+ PROGRAMME. AGREEMENT NUMBER - 2015 - $0860 /$ 059 - 001 on the award of a grant to support an action initiated under the Jean Monnet Activities within the ERASMUS+ PROGRAMME PROJECT NUMBER - 566760-EPP-1-2015-1-EPPJMO-MODULE.

\section{References}

Balitskiy, S.; Bilan, Y.; Strielkowski, W. 2014. Energy security and economic growth in the European Union, Journal of Security \& Sustainability Issues 4(2): 125-132. http://dx.doi.org/10.9770/jssi.2014.4.2(2)

Baublys, J.; Miškinis, V.; Konstantinavičiūtè, I.; Lekavičius, V. 2015. Energy efficiency as precondition of energy security, Journal of Security and Sustainability Issues 4(3): 197-208. http://dx.doi.org/10.9770/jssi.2015.4.3(1)

Bilan, Y.; Strielkowski, W.; Karbach, R.; Mentel, G. 2017. Secure development of country and competitiveness issues: case of Germany's energy security, Journal of Security \& Sustainability Issues 6(3): 331-342. http://dx.doi.org/10.9770/jssi.2017.6.3(1)

Burrage, M. 2016. Myth and paradox of the single market: How the trade benefits of EU membership have been mid-sold. London: Civitas

Č́belková, I.; Strielkowski, W. 2013. Is the level of taxation a product of culture? A cultural economics approach. Society and Economy 35(4): 513-529 http://dx.doi.org/10.1556/SocEc.2013.0007

Cini, M.; Pérez-Solórzano, B. N. 2015. European Union politics. Oxford: Oxford University Press. 
de Espona, R. J. 2016. Energy Security, resilience and Critical InfrastructureProtection: Spanish Puertollano Refinery crisis case, Journal of Security and Sustainability Issues 5(3): 323-328. http://dx.doi.org/10.9770/jssi.2016.5.3(2)

Dreyer, I.; Stang, G. 2013. What energy security for the EU. EUISS Brief Issue No. 39.

Eurostat. 2016. EU energy balances. Retrieved from: http://ec.europa.eu/eurostat/web/energy/data/energy-balances

Genys, D. 2016. Towards sustainable development: tackling relations between energy security and social exclusion, Journal of Security and Sustainability Issues 6(1): 27-36. DOI: http://dx.doi.org/10.9770/jssi.2016.6.1(2)

Jefremov, V.; Rubanovskis, A. 2015. Towards a sustainable Latvian energy resources and energy markets in the context of the EU, Journal of Security and Sustainability Issues 4(3): 552-563. http://dx.doi.org/10.9770/jssi.2015.4.3(5)S

Karl, W. 2016. Brexit and the future of the Euro. Retrieved from https://polcms.secure.europarl.europa.eu/cmsdata/upload/fc602d589052-48ae-aadc-4a183227e689/WHELAN.pdf

Kauders, D. 2016. Understanding Brexit Options: What Future for Britain? Sparkling Books

Koudelková, P.; Strielkowski, W.; Hejlová, D. 2015. Corruption and System Change in the Czech Republic: Firm-level Evidence, DANUBE: Law and Economics Review 6(1): 25-46.

Macshane, D. 2015. Brexit: how Britain will leave Europe. London: Taurus

Navickas, V.; Švažas, M.; Guščinskienė, J. 2017. Biomass clusters as a national energy security factor, Journal of Security and Sustainability Issues 6(3): 523-531. http://dx.doi.org/10.9770/jssi.2017.6.3(16)

Oates, M.; Melia, A.; Ferrando, V. 2017. Energy balancing accross cities: Virtual Power Plant prototype and iURBAN case studies, Entrepreneurship and Sustainability Issues 4(3): 351-363. http://dx.doi.org/10.9770/jesi.2017.4.3S(10)

Oliver, T., 2016. Now! That's what I call Brexit. Delving into the Brexicon. London School of Economics and Political Science, Public Policy Group, London, UK.

Oliver, T.; Williams, M. J. 2016. Special relationships in flux: Brexit and the future of the US-EU and US-UK relationships, International Affairs 92(3): 547-567. http://dx.doi.org/10.1111/1468-2346.12606

Rovelli, R. 2016. Wage coordination in new and old EU member states. IZA World of Labor, Working paper No. 222.

Schröder, M.; Prause, G. 2015. Risk management for green transport corridors, Journal of Security and Sustainability Issues 5(2): 229-239. http://dx.doi.org/10.9770/jssi.2015.5.2(8)

Shipman, T. 2017. All out war, London: William Collins.

Strielkowski, W.; Čábelková, I. 2015. Religion, Culture, and Tax Evasion: Evidence from the Czech Republic. Religions 6(2): 657-669. http://dx.doi.org/10.3390/rel6020657

Strielkowski, W.; Lisin, E. 2013. Energy economics and policy of renewable energy sources in the European Union. International Journal of Energy Economics and Policy3(4): 333-340

Strielkowski, W.; Lisin, E.; Tvaronavičienė, M. 2016a. Towards energy security: sustainable development of electrical energy storage, Journal of Security and Sustainability Issues 6(2): 235-244. http://dx.doi.org/10.9770/jssi.2016.6.2(4)

Strielkowski, W.; Tumanyan, Y.; Kalyugina, S. 2016b. Labour Market Inclusion of International Protection Applicants and Beneficiaries, Economics \& Sociology 9(2): 293-302. http://dx.doi.org/10.14254/2071-789X.2016/9-2/20

Tvaronavičienè, M. 2016. Entrepreneurship and energy consumption patterns: case of households in selected countries, Entrepreneurship and Sustainability Issues 4(1): 74-82. http://dx.doi.org/10.9770/jesi.2016.4.1(7)

Tvaronavičienė, M.; Mačiulis, A.; Lankauskienė, T.; Raudeliūnienė, J.; Dzemyda, I. 2015. Energy security and sustainable competitiveness of industry development, Economic research = Ekonomska istraživanja 28 (1): 502-516. http://dx.doi.org/10.1080/133167 $7 \mathrm{x} .2015 .1082435$

Vibert, F. 2015. On the edge: David Cameron's EU renegotiation strategies. London School of Economics and Political Science, Public Policy Group, London, UK. 